\title{
PENGARUH JIGSAW BERBANTUAN MEDIA GAMBAR TERHADAP HASIL BELAJAR IPA KELAS V DI SD GUGUS V
}

\author{
Luh Juli Utariasih ${ }^{1}$, I Nyoman Jampel ${ }^{2}$, I Nyoman Murda ${ }^{3}$ \\ 1, 3Jurusan PGSD, 2Teknologi Pendidikan, Universitas Pendidikan Ganesha, Singaraja, \\ e-mail: juliutari88@gmail.com1, jampel@undiksha.co.id2, inyoman.murda@undiksha.co.id3
}

\begin{abstract}
Abstrak
Penelitian ini bertujuan untuk mengetahui perbedaan hasil belajar IPA antara kelompok siswa yang mengikuti pembelajaran dengan menggunakan model pembelajaran kooperatif tipe jigsaw berbantuan media gambar dan kelompok siswa yang tidak menggunakan model pembelajaran kooperatif tipe jigsaw berbantuan media gambar. Penelitian ini termasuk penelitian eksperimen semu (Quasi Eksperimen), dengan rancangan Nonequivalent Post-Test Only Control Group Design. Populasi penelitian ini adalah seluruh siswa kelas V SD di Gugus V Kecamatan Banjar. Sampel ditentukan dengan menggunakan teknik random sampling. Metode pengumpulan data hasil belajar menggunakan metode tes pilihan ganda. Data yang diperoleh dianalisis menggunakan teknik analisis statistik deskriptif dan statistik inferensial uji-t dengan rumus polled varians. Hasil Penelitian menunjukkan bahwa terdapat perbedaan yang signifikan pada hasil belajar IPA antara kelompok siswa yang mengikuti pembelajaran dengan menggunakan model pembelajaran kooperatif tipe jigsaw berbantuan media gambar dan kelompok siswa yang tidak menggunakan model pembelajaran kooperatif tipe jigsaw berbantuan media gambar. pada siswa kelas V SD di Gugus V Kecamatan Banjar. Hal ini ditunjukkan oleh hasil analisis hipotesisdengan uji-t, $t_{\text {hitung }}(3,292732)>\mathrm{t}_{\text {tabel }}(2,022)$. Selanjutnya, rata-rata (mean) kelompok eksperimen $(20,64)$ lebih besar dari pada rata-rata (mean) kelompok kontrol $(18,2)$. Dengan demikian, pembelajaran dengan menggunakan model pembelajaran kooperatif tipe jigsaw berbantuan media gambar berpengaruh terhadap hasil belajar IPA siswa kelas V SD di Gugus V Kecamatan Banjar tahun ajaran 2017/2018.
\end{abstract}

Kata kunci: model koopertatif tipe jigsaw, hasil Belajar,IPA.

\begin{abstract}
This study was aimed to know the differentciateof the result study at sains between group of stundents who followed the study with cooperative jigsaw type that combined by picture media and the students who did not used cooperative jigsaw type combined by picture media. This study was belong to quasi exsperiment with Nonequivalent Post-Test Only Control Group Design. The population of this study was all of the five grade student at five troop in Banjar subdistrict. The teknic model defermined by used random sampling. The method to collected date of resuit study used multipie choice method. The date collected analysis by statistic descriptive and statistic inferensial t-experimen technic with formulas polled varians.the result of the study showed that there are significance differlance on the sains result study between the group of students who was followed study with cooperative jigsaw type that combinated by picture media and group of students who did not used study model cooperative jigsaw type that combined by picture on five grade students at troop in banjar subdistrict. That all showed by the hipotesis analysis result with $t$-experimen $t_{\text {hitung }}(3,292732)>t_{\text {tabel }}(2,022)$. Next the mean of experiment group was $(20,64)$ the result was high more that mean of control group $(18,2)$.it's mean that the study that used study model cooperative jigsaw type combined by picture gave effect of sains study result gave grade student at five troop in Banjar subdistrict in the academic year 2017/2018.
\end{abstract}

Keywords : coperative jigsaw type model, resul of study sains. 


\section{Pendahuluan}

IPA merupakan salah satu mata pelajaran pokok dalam kurikulum pendidikan di Indonesia, termasuk pada jenjang sekolah dasar. Mata pelajaran IPA merupakan mata pelajaran yang memegang peranan penting dalam kehidupan sehari-hari, sebab IPA melatih siswa berfikir logis, rasional, kritis dan kreatif atau berpikir secara ilmiah. Pendidikan IPA juga memiliki peranan yang sangat penting dalam pembentukan kepribadian dan perkembangan intelektual anak. Oleh karena pentingnya pendidikan IPA di SD, maka sangat diperlukan pembelajaran yang sesuai dengan materi yang ada, sehingga siswa belajar IPA secara bermakna. Pembelajaran IPA di SD bertujuan agar siswa mampu menerapkan berbagai konsep-konsep IPA untuk meningkatkan kesadaran terhadap Tuhan Yang Maha Esa, berperan aktif dalam menjaga kelestarian lingkungan.

Pembelajaran IPA di SD seharusnya memberikan pengalaman belajar langsung melalui penggunaan dan pengembangan suatu keterampilan proses dan sikap ilmiah. Pengalaman belajar langsung dapat dilakukan melalui pemecahan berbagai macam-macam masalah yang berhubungan tentang permasalahan yang ada di kehidupan sehari-hari. Pemecahan masalah dapat mendorong siswa agar lebih aktif, mengontruksi, pengetahuan sehingga diperoleh hasil belajar IPA yang diharapkan. Berbagai upaya yang dilakukan untuk meningkatkan hasil belajar IPA telah dilakukan telah menunjukan keberhasilan, namun masih terdapat sekolah-sekolah yang siswanya masih mendapat hasil belajar IPA rendah. Hal ini menunjukan bahwa pembelajaran IPA di SD belum mengutamakan keaktifan siswa untuk mengonstruksi pengetahuannya pengalaman yang diperoleh siswa dalam belajar yaitu siswa hanya membaca buku sumber dan menghafal. Pernyataan tersebut diperkuat oleh fakta-fakta yang ditemukan berdasarkan hasil observasi yang dilakukan di SD Gugus V Kecamatan banjar.

Berdasarkan hasil wawancara yang dilakukan pada tanggal 11-12 Desember 2017 terhadap guru kelas V di SD Gugus V Kecamatan Banjar mengenai hasil belajar siswa, guru menyatakan bahwa hasil belajar siswa kelas $\mathrm{V}$ masih dalam kategori rendah. Rendahnya hasil belajar dikarenakan kurangnya keaktifan siswa dalam proses pembelajaran, pada saat guru menjelaskan materi pembelajaran siswa sangat lambat untuk menerima materi yang diberikan oleh guru, siswa kurang aktif dalam mengikuti pembelajaran sehari-hari. Pada saat guru mengajukan pertanyaan hanya 3 atau 4 orang siswa yang mampu menjawab, yaitu siswa yang memang mendapat peringkat. Guru jarang menggunakan model pembelajaran yang kooperatif pada saat mengajar di kelas. Hal tersebut akan berdampak pada hasil belajar siswa.

Berdasarkan hasil pengamatan yang dilakukan pada tanggal 11-12 Desember 2017 terhadap guru kelas $\mathrm{V}$ bahwa masih banyak siswa yang mempunyai sifat individualisme yang artinya siswa yang memiliki kemampuan tinggi tidak mau berbaur dengan siswa yang memiliki kemampuan yang rendah pada saat melakukan proses pembelajaran di dalam kelas, kurangnya guru menggunakan media pembelajaran pada saat mengajar, guru hanya menggunakan metode ceramah sehingga pembelajaran hanya terpusat pada guru hal tersebut yang menyebabkan siswa sering bercerita dengan teman sebangkunya tanpa mendengarkan penjelasan dari guru. sehingga berdampak pada hasil belajar yang ingin dicapai. Berdasarkan hasil studi dokumen pada tanggal 11-12 Desember 2017, diperoleh data seperti tersaji pada Tabel berikut.

Tabel 1 Rata-Rata Nilai UTS Mata Pelajaran IPA Siswa Kelas V SD di Gugus V Kecamatan Banjar Semester I Tahun Pelajaran 2016/2017

\begin{tabular}{cccc}
\hline No & Sekolah & $\begin{array}{c}\text { Rata-rata Nilai } \\
\text { UTS }\end{array}$ & KKM \\
\hline 1 & SD N 1 Sidetapa & 63,1 & 63 \\
2 & SDN 2 Sidetapa & 60,35 & 63 \\
3 & SD N 3 Sidetapa & 60,23 & 63 \\
4 & SD N 1 Cempaga & 60,57 & 63 \\
\hline
\end{tabular}




\begin{tabular}{lccc}
\hline 5 & SD N 2 Cempaga & 63 & 63 \\
6 & SD N 3 Pedawa & 61,11 & 63 \\
7 & SD N 4 Pedawa & 63,26 & 63 \\
\hline
\end{tabular}

(Sumber: Dokumen Guru SD di Gugus V Kec. Banjar,2017)

Berdasarkan hasil UTS pada Tabel 1 diatas, terlihat rata-rata nilai hasil belajar kognitif pada mata pelajaran IPA siswa kelas V SD di gugus $V$ Kecamatan Banjar berada pada kategori rendah. Dari hasil rata-rata UTS SD Di Gugus V Kecamatan Banjar terdapat dua SD yang mendapat nilai UTS di atas rata-rata karena sebabkan oleh jumlah siswa pada SD tersebut sangat sedikit dan semua SD masih menggunakan kurikulum KTSP. Sehinga guru lebih mudah mengawasi siswa di dalam kelas. Dari permasalahan yang telah terpapar diatas perlu dicarikan solusi yang tepat untuk mengatasi permasalahan tersebut. Solusi yang tepat yaitu salah satunya adalah dengan menerapkan model pembelajaran kooperatif tipe Jigsaw dengan berbantuan media gambar.

Model pembelajaran kooperatif tipe jigsaw adalah sebuah model belajar kooperatif yang menitikberatkan kepada kerja kelompok siswa dalam bentuk kelompok kecil yang terdiridari 4 sampai 6 orang. Seperti diungkapkan oleh Lie, (dalam Rusman, 2017:309), bahwa "pembelajaran kooperatif tipe jigsaw ini merupakan model belajar kooperatif dengan cara siswa belajar dalam kelompok kecil yang terdiri dari empat sampai enam orang secara heterogen dan siswa bekerja sama saling ketergantungan positif dan bertanggung jawab secara mandiri". Menurut Lei (dalam Rusman, 2017:310) menyatakan bahwa jigsaw merupakan salah satu tipe atau model pembelajaran kooperatif yang fleksibel. Menurut Menurut Kurniasih, (2015:24) menyatakan bahwa jigsaw merupakan model pembelajaran kooperatif yang didesain untukmeningkatkan rasa tanggung jawab siswa terhadap pembelajarannya sendiri dan juga pembelajaran orang lain.

Model pembelajaran tipe jigsaw yang diterapkan di SD akan memperoleh hasil belajar yang lebih baik, prestasi lebih baik, mempunyai sikap yang lebih baik dan positif terhadap pembelajaran. Pembelajaran kooperatif tipe jigsaw berbantuan media gambar akan membuat proses pembelajaran di dalam kelas akan menjadi lebih menyenangkan dan perhatian siswa akan terpusat pada pelajaran yang diberikan oleh guru Pembelajaran kooperatif tipe jigsaw akan membuat suasana kelas menjadi aktif apabila pembelajaran diiringi dengan menggunakan suatu media pembelajaran. Menurut Briggs (dalam Mudlofir Ali dan evi, 2016:124) 'menyatakan bahwa media pembelajaran adalah segala alat fisik yang dapat menyajikan pesan serta merangsang peserta didik untuk belajar'. Pembelajaran kooperatif tipe jigsaw akan membuat suasana kelas menjadi aktif.

Berdasarkan hal tersebut, pembelajaran dengan model pembelajaran kooperatif tipe jigsaw memiliki pengaruh terhadap hasil belajar siswa. Pembelajaran kooperatif tipe jigsaw dipilih karena memiliki kelebihan dalam bidang diskusi kelompok, dalam pembelajaran jigsaw lebih mementingkan hasil kelompok dari pada individu. Sehingga semua siswa dapat bergaul dengan temannya dan dalam suatu kelompok aka nada siswa yg berbeda-beda atau siswa yang heterogen. Namun besarnya pengaruh pembelajaran dengan kooperatif tipe jigsaw belum dapat diketahui secara pasti.

Untuk membuat pembelajaran di dalam kelas menjadi lebih aktif dan menyenangkan maka di dalam proses pembelajaran kooperatif tipe jigsaw perlu adanya suatu media, salah satunya yaitu media gambar. Djamarah dan Aswan Zain, (2006:120) menyatakan bahwa kata "media" berasal dari bahasa Latin dan merupakan bentuk jamak dari kata "medium", yang secara harfiah berarti "perantara atau pengantar". Dengan demikian media merupakan wahana penyalur informasi belajar atau penyalur pesan. Dalam proses belajar mengajar kehadiran media mempunyai arti yang cukup penting. Sebagai komponen sistem pembelajaran, media memiliki fungsi yang berbeda dengan fungsi komponen-komponen lainnya, yaitu sebagai komponen yang dimuati pesan penbelajaran untuk disampaikan kepada pelajar. Menurut Ibrahim, dkk (dalam tegeh 2010:8) menjelaskan fungsi media pembelajaran ditinjau dari dua hal, yaitu: proses pembelajaran sebagai proses komunikasi dan kegiatan interaksi antara siswa dan lingkungannya. Ditinjau dari proses pembelajarannya sebagai proses komunikasi, maka fungsi media adalah sebagai pembawa 
informasi dari sumber ke penerima. Ditinjau dari proses pembelajaran sebagai kegiatan interaksi antara siswa dan lingkungannya, maka fungsi dapat diketahui berdasarkan adanya kelebihan media dan hambatan komunikasi yang memungkinkan timbul dalam proses pembelajaran.

Berdasarkan pemikiran tersebut maka dilakukan penelitian yang berjudul berjudul "Pengaruh Model Pembelajaran Kooperatif Tipe Jigsaw Berbantuan Media Gambar Terhadap Hasil Belajar IPA Kelas V SD Gugus V Kecamatan Banjar Tahun Pelajaran 2017/2018".

\section{Metode}

Tempat pelaksanaan penelitian ini bertempat di SD Gugus V Kecamatan Banjar Kabupaten Buleleng. Gugus ini terdiri dari 7 SD, SDN 3 Sidetapa sebagai kelompok eksperimen, dan SDN 1 Sidetapa sebagai kelompok kontrol. Penelitian ini dilaksanakan dalam rentang waktu semester II (semester genap) tahun pelajaran 2017/2018. Penelitian ini menggunakan desain penelitian kuasi eksperimen dengan rancangan Non-Equivalendt Post Test Only Control Group Design.

Populasi dari penelitian ini adalah seluruh siswa kelas V SD di Gugus V Kecamatan Banjar yang terdiri atas 7 (tujuh) SD, Jumlah seluruh anggota populasi adalah 173 siswa. Sebelum menentukan kelas sampel, dilakukan uji kesetaraan terhadap populasi penelitian. Berdasarkan hasil uji kesetaraan menggunakan uji ANAVA, diperoleh seluruh populasi setara yang artinya kemampuan hasil belajar IPA siswa SD Gugus V Kecamatan Banjar tahun pelajaran 2017/2018 relatif sama. Selanjutnya, dilakukan pengambilan sampel dengan teknik random sampling, yaitu melalui sistem undian. Berdasarkan hasil pengundian, diperoleh dua kelas sampel yaitu kelas V SD N 3 Sidetapa dan kelasIV SD N 1 Sidetapa. Kelas sampel yang telah didapatkan kemudian diundi lagi untuk menentukan kelompok eksperimen dan kontrol. Dari hasil pengundian diperoleh kelas V SD N 3 Sidetapa sebagai kelompok eksperimen dan kelas V SD N 1 Sidetapa sebagai kelompok kontrol. Kelompok eksperimen diberikan perlakuan dengan menggunakan model pembelajaran kooperatif tipe jigsaw berbantuan media gambar dan kelompok control tidak menggunakan model pembelajaran kooperatif tipe jigsaw berbantuan media gambar.

Metode pengumpulan data yang dikumpukan dalam penelitian ini adalah hasil belajar ranah kognitif IPA siswa kelas V SD di Gugus V Kecamatan Banjar. Metode pengumpulan data yang sesuai digunakan untuk memperoleh hasil belajar ranah kognitif siswa adalah metode tes, tes ini diberikan pada saat post-test. Agar memenuhi syarat instrument yang baik, maka dilakukan uji validitas tes, uji reliabilitas tes, uji daya beda tes, dan uji tingkat kesukaran tes. Sebelum terjun ke lapangan harus dilakukan uji validitas isi dilakukan dengan uji validitas Gregory atas penilaian dari ahli, setelah mendapatkan hasil perhitungan validitas isi kemudian instrument dapat diujicobakan ke lapangan, kemudian hasil uji coba dianalisis lebih lanjut dengan uji validitas, reliabilitas, tingkat kesukaran test dan daya beda.

Teknik analisis data yang digunakan adalah statistik deskriptif dan statistik inferensial. Analisis deskriptif dilakukan dengan menghitung mean, median, modus, standar deviasi, dan varians terhadap masing-masing kelompok. Mean, median, dan modus pemahaman konsep IPA siswa selanjutnya disajikan ke dalam poligon. Tinggi rendahnya kualitas variabel-variabel penelitian dapat ditentukan dari skor rata-rata (mean) tiap-tiap variabel yang dikonversikan ke dalam PAP Skala Lima. Statistik inferensial bertujuan untuk menguji hipotesis penelitian. Sebelum melakukan pengujian hipotesis, dilakukan beberapa uji prasyarat analasis data, yaitu uji normalitas dan homogenitas varians. Pengujian hipotesis terhadap hipotesis nol ( $\mathrm{H} 0)$ menggunakan uji-t sampel independent (tidak berkorelasi) dengan rumus polled varians.

\section{Hasil dan Pembahasan}

Data dalam penelitian ini adalah skor hasil belajar IPA siswa sebagai akibat dari penerapan model pembelajaran kooperatif tipe jigsaw berbantuan media gambar pada 
kelompok eksperimen dan model pembelajaran tidak menggunakan pembelajaran kooperatif tipe jigsaw berbantuan media gambar pada kelompok kontrol. Rekapitulasi perhitungan data hasil belajar IPA siswa disajikan pada Tabel 1.

Tabel 1. Rekapitulasi Hasil Perhitungan Skor Hasil Belajar IPA Siswa Kelas V

\begin{tabular}{|l|l|l|}
\hline Statistik & $\begin{array}{l}\text { Kelompok } \\
\text { Eksperimen }\end{array}$ & $\begin{array}{l}\text { Kelompok } \\
\text { kontrol }\end{array}$ \\
\hline Rentangan data & 9 & 9 \\
\hline $\begin{array}{l}\text { Jumlah kelas } \\
\text { interval }\end{array}$ & 5 & 5 \\
\hline $\begin{array}{l}\text { Panjang kelas } \\
(\mathrm{P})\end{array}$ & 2 & 2 \\
\hline Mean (M) & 20.64 & 18,2 \\
\hline Median (Md) & 21.38 & 18,1 \\
\hline Modus (Mo) & 22.79 & 16,0 \\
\hline
\end{tabular}

Berdasarkan data pada Tabel 1, diketahui bahwa nilai mean, median dan modus data pemahaman konsep IPA siswa kelompok eksperimen berbeda dengan kelompok kontrol. Selanjutnya mean, median, dan modus data pemahaman konsep IPA siswa pada kelompok eksperimen dan kontrol disajikan ke dalam poligon seperti pada Gambar 1 dan 2.

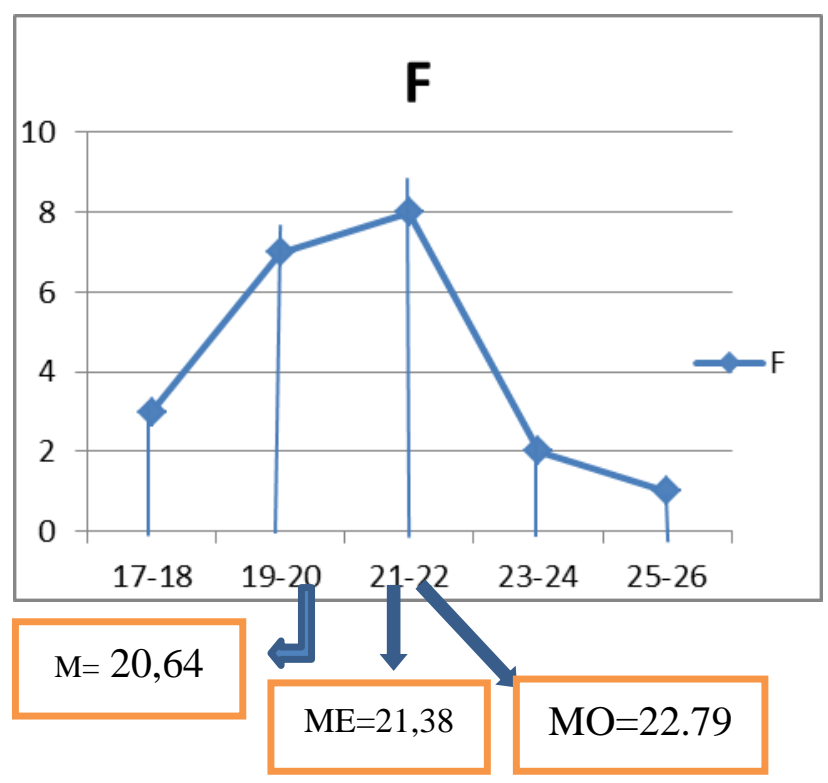

Gambar 1. Poligon Data Hasil Belajar IPA Siswa kelompok Eksperimen 


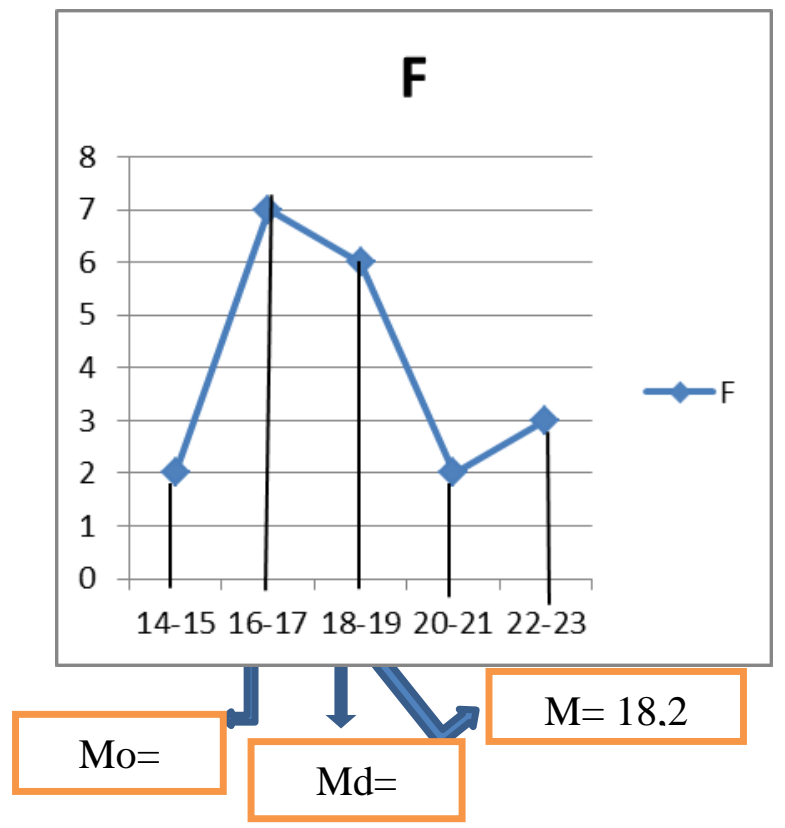

\section{Gambar 2. Poligon Data Hasil Belajar IPA Siswa Kelompok Kontrol}

Berdasarkan Gambar 1 modus lebih besar dari median dan median lebih besar dari mean $(\mathrm{Mo}>\mathrm{Md}>\mathrm{M})$. Dengan demikian, sebaran data hasil belajar IPA siswa kelompok eksperimen adalah kurve juling negatif, yang artinya sebagian besar skor siswa kelompok eksperimen cenderung tinggi. Skor rata-rata data hasil belajar IPA siswa kelompok eksperimen adalah 20,64. Jika skor rata-rata tersebut dikonversikan ke dalam PAP Skala Lima, maka berada pada kategori sangat tinggi.

Berdasarkan Gambar 2, diketahui bahwa modus lebih kecil dari median dan median lebih kecil dari mean (Mo $<\mathrm{Md}<\mathrm{M}$ ). Dengan demikian, sebaran data hasil belajar IPA siswa kelompok kontrol adalah kurve juling positif, yang artinya sebagian besar skor siswa kelompok kontrol cenderung rendah. Skor rata-rata data hasil belajar IPA siswa kelompok kontrol adalah 18,2. Jika skor rata-rata tersebut dikonversikan ke dalam PAP Skala Lima, maka berada pada kategori tinggi.

Secara deskriptif, rata-rata skor hasil belajar IPA pada kelompok siswa yang mengikuti pembelajaran dengan model pembelajaran kooperatif tipe jigsaw berbantuan media gambar lebih tinggi dibandingkan kelompok siswa yang mengikuti pembelajaran tidak menggunakan model pembelajaran kooperatif tipe jigsaw berbantuan media gambar, yaitu 20,64 > 18,2. Hal ini menunjukkan bahwa model pembelajaran kooperatif tipe jigsaw berbantuan media gambar lebih efektif dalam meningkatkan hasil belajar IPA dibandingkan pembelajaran tidak menggunakan model pembelajaran kooperatif tipe jigsaw berbantuan media gambar.

Berdasarkan hasil uji prasyarat analisis data, diperoleh data hasil belajar IPA pada kelompok siswa yang mengikuti pembelajaran dengan model pembelajaran kooperatif tipe jigsaw berbantuan media gambar dan kelompok siswa yang tidak menggunakan model pembelajaran kooperatif tipe jigsaw berbantuan media gambar adalah berdistribusi normal dan varians kedua kelompok homogen. Selanjutnya dilakukan pengujian hipotesis terhadap hipotesis nol $(\mathrm{H} 0)$ dengan menggunakan uji-t sampel independent (tidak berkorelasi) dengan rumus polled varians. Rangkuman uji hipotesis disajikan pada Tabel 2.

Tabel 2. Rangkuman Hasil Uji Hipotesis

\begin{tabular}{|l|l|l|l|l|l|l|}
\hline Data & Sampel & $\begin{array}{l}\text { Jumlah } \\
\text { siswa }\end{array}$ & Mean & $s^{2}$ & $t_{\text {hit }}$ & $t_{\text {tab }}$ (t.s.5\%) \\
\hline $\begin{array}{l}\text { Hasil } \\
\text { Belajar }\end{array}$ & Eksperimen & 21 & 20,64 & 5,63 & \multirow{2}{*}{3,292732} & 2,022 \\
\cline { 2 - 5 } & Kontrol & 20 & 18,2 & 5,62 & \\
\hline
\end{tabular}


Berdasarkan Tabel 2, diketahui bahwa nilai thitung lebih besar dari nilai ttabel, yaitu $(3,292732>2,022)$ sehingga $\mathrm{H} 0$ ditolak dan $\mathrm{H} 1$ diterima. Dengan demikian, dapat diinterpretasikan bahwa terdapat perbedaan yang signifikan hasil belajar siswa pada mata pelajaran IPA antara kelompok siswa yang mengikuti pembelajaran dengan model pembelajaran kooperatif tipe jigsaw berbantuan media gambar dan kelompok siswa yang tidak menggunakan model pembelajaran kooperatif tipe jigsaw berbantuan media gambar di Gugus V Kecamatan Banjar.

Berdasarkan penelitian yang dilakukan, pembelajaran dengan model pembelajaran kooperatif tipe jigsaw berbantuan media gambar yang digunakan dalam kelompok eksperimen dan pembelajaran tidak menggunakan model pembelajaran kooperatif tipe jigsaw berbantuan media gambar yang digunakan dalam kelompok kontrol menunjukan pengaruh yang berbeda pada hasil belajar IPA. Hal ini dapat dilihat dari perbedaan rata-rata skor hasil belajar IPA pada kedua kelompok dan hasil uji-t. Secara deskriptif, hasil belajar IPA siswa kelompok eksperimen lebih tinggi dibandingkan dengan siswa kelompok kontrol. Tinjauan ini didasarkan pada rata-rata skor dan kecenderungan skor hasil belajar IPA yang diperoleh kedua kelompok. Rata-rata skor hasil belajar IPA siswa kelompok eksperimen adalah 20,64 (kategori sangat tinggi), sedangkan rata-rata skor hasil belajar IPA siswa kelompok kontrol adalah 18,2 (kategori tinggi).

Selanjutnya, berdasarkan analisis data menggunakan uji-t, diketahui $t=3,292732$ dan $\mathrm{t}(\mathrm{db}=39$ pada taraf signifikansi $5 \%)=2,022$. Hasil perhitungan tersebut menunjukan bahwa $\mathrm{t}$ lebih besar dari $\mathrm{t}(\mathrm{t}>\mathrm{t})$, sehingga hasil penelitian adalah signifikan. Artinya, terdapat perbedaan yang signifikan pada hasil belajar IPA antara kelompok siswa yang belajar dengan menggunakan model pembelajaran kooperatif tipe jigsaw berbantuan media gambar dan kelompok siswa yang belajar tidak menggunakan model pembelajaran kooperatif tipe jigsaw berbantuan media gambar, menunjukan bahwa pembelajaran dengan tutor sebaya berpengaruh terhadap hasil belajar IPA siswa.

Temuan penelitian yang menunjukan bahwa pembelajaran kooperatif tipe jigsaw berpengaruh terhadap hasil belajar IPA siswa kelas $\mathrm{V}$ dikarenakan oleh beberapa hal.

Pertama, pembelajaran kooperatif tipe jigsaw memberikan kesempatan kepada siswa untuk membentuk sebuah kelompok belajar yang terdiri dari 4 sampai 6 orang. Hal tersebut melatih siswa untuk saling bekerjasama dalam memecahkan suatu masalah dalam pembelajaran, sehingga siswa terlatih untuk mengeluarkan ide atau pendapatnya sendiri. Selain hal tersebut, siswa juga lebih antusias dalam mengikuti proses pembelajaran. Pembelajaran dengan menggunakan model pembelajaran kooperatif tipe jigsaw membuat siswa merasa lebih dekat, akarab, nyaman, percaya diri, dan bertanggung jawab pada tugasnya masing-masing. Siswa pun mendapat kesempatan untuk saling bertukar fikiran dengan temannya. Dengan demikian, pembelajaran akan menjadi lebih bermakna dan menyenangkan. Hal seperti itu akan menumbuhkan minat dan motivasi siswa untuk lebih aktif dan giat belajar, sehingga hasil belajar siswa menjadi lebih baik.

Kedua, dengan menggunakan model pembelajaran kooperatif tipe jigsaw keterlibatan guru sebagai motivator dalam proses pembelajaran akan membuat suasana belajar akan lebih hidup, harmonis dan menyenangkan. Tidak hanya itu, siswa dan guru dapat saling berinteraksi antara satu dan yang lain. Dengan adanya interaksi maka pembelajaran akan lebih aktif, sehingga siswa dan guru akan menjadi lebih akrab.

Ketiga, pembelajaran dengan menggunakan media pembelajaran. Dalam proses pembelajaran siswa lebih senang dan aktif jika diiringi dengan menggunakan media pembelajaran guru menjadi lebih termotivasi lebih aktif dan kreatif dalam merancang proses pembelajaran di dalam kelas, karena media dapat mewakili apa yang guru ucapkan dan membantu guru dalam menjelaskan bahan ajar. Selain itu guru juga memberikan penghargaan berupa gambar bintang tersenyum, dan tepuk tangan bagi siswa yang mampu menjawab soal yang diberikan oleh guru hal tersebut membuat siswa lebih aktif, siswa menjadi lebih antusias dalam mengikuti proses pembelajaran. Hasilnya terlihat pada saat berdiskusi siswa berlomba-lomba untuk menjawab pertanyaan agar mendapat tepuk tangan, dan bintang sebagai poin. 
Berbeda halnya dengan siswa yang mengikuti pembelajaran yang tidak menggunakan model pembelajaran kooperatif tipe jigsaw berbantuan media gambar. Dalam penelitian ini, guru lebih banyak mendominasi kegiatan pembelajaran, siswa hanya berperan sebagai pendengar yang pasif dan mengerjakan apa yang disuruh guru, serta dalam pemberian tugas guru hanya memberikan tugas yang ada di buku paket saja. Sehingga siswa tidak dapat memecahkan masalah-masalah yang dihadapi dalam pembelajaran, karena kurangnya pemahaman dan pengetahuan yang dimiliki oleh siswa. Selain hal tersebut, dalam pembelajaran yang tidak menerapkan model pembelajaran kooperatif tipe jigsaw siswa jarang berinteraksi dengan temannya selama proses pembelajaran berlangsung.

Selanjutnya, berkaitan dengan meningkatnya rata-rata skor hasil belajar siswa pada kelompok kontrol yang tidak diberikan perlakuan namun berada pada kategori tinggi dipengaruhi oleh beberapa hal. Pertama, saat pembelajaran kelas kontrol, peran guru sangat mempengaruhi meningkatnya rata-rata hasil belajar siswa. Guru mampu memotivasi siswa dengan memberikan penghargaan berupa tepuk tangan, sehingga siswa menjadi lebih antusias dan aktif dalam proses pembelajaran.

Perbedaan cara pembelajaran antara pembelajaran dengan menggunakan model pembelajaran kooperatif tipe jigsaw berbantuan media gambar dan pembelajaran yang tidak menerapkan model pembelajaran kooperatif tipe jigsaw berbantuan media gambar tentunya akan memberikan dampak yang berbeda pula terhadap pemahaman dan pengetahuan yang didapat siswa, sehingga akan mempengaruhi hasil belajar siswa itu sendiri.

Temuan peneliti tersebut seperti dipaparkan di atas sesuai dengan hasil penelitian sebelumnya yang dilakukan oleh dilakukan oleh Sahin Abdullah Tahun 2010, yang berjudul Effects of jigsaw II technique on academic achievement and attitudes to written expression course. Dari hasil penelitian tersebut ditemukan bahwa hasil Analisis statistik menunjukkan bahwa ada signifikan perbedaan antara kelompok eksperimen dan kontrol dalam hal sikap mereka, akademik prestasi, dan retensi yang mendukung kelompok eksperimen. Selain itu, ditentukan bahwa Siswa kelompok eksperimen memiliki pandangan positif tentang penggunaan teknik Jigsaw. Selanjutnya penelitian yang dilakukan oleh Ni Kd Liana Karisma tahun 2015, yang berjudul Penerapan Model Pembelajaran Jigsaw Pada Mata Pelajaran IPA Untuk Meningkatkan Hasil Belajar Siswa Kelas IV. Penelitian tersebut membuktikan bahwa model pembelajaran kooperatif tipe jigsaw dapat meningkatkan hasil belajar sebesar $85 . \%$.

Berdasarkan paparan di atas, dapat dinyatakan bahwa pembelajaran dengan menggunakan model pembelajaran kooperatif tipe jigsaw berpengaruh terhadap hasil belajar IPA siswa kelas V SD di Gugus V Kecamatan Banjar, Kabupaten Buleleng tahun ajaran 2017/2018. Maka dari itu, pembelajaran ini dapat diterapkan sebagai variasi dalam kegiatan pembelajaran sehingga siswa tidak mudah jenuh, dan pembelajaran menjadi lebih variatif. Akhirnya, hasil belajar pun dapat dioptimalkan.

\section{Simpulan dan Saran}

Berdasarkan hasil pengujian hipotesis dan pembahasan di atas, ditemukan bahwa terdapat perbedaan yang signifikan hasil belajar IPA antara kelompok siswa yang menggunakan pembelajaran dengan menggunakan model pemmbelajaran kooperatif tipe jigsaw berbantuan media gambar dan kelompok siswa yang mengikuti pembelajaran tidak menggunakan model pembelajaran kooperatif tipe jigsaw berbantuan media gambar pada sswa kelas V SD di Gugus V KecamatanBanjar, Kabupaten buleleng tahun ajaran 2017/2018. Hal ini dapat dilihat berdasarkan hasil pengujian hipotesis, diperoleh sebesar 3,292732 , sedangkan dengan $\mathrm{db}=39$ dan taraf signifikansi $5 \%$ adalah 2,022 . Hal ini berarti, lebih besar dari ( $>$ ), sehingga $\mathrm{H}$ ditolak dan $\mathrm{H}$ diterima.

Dengan demikian dapat disimpulkan bahwa pembelajaran dengan menggunakan model pemmbelajaran kooperatif tipe jigsaw berbantuan media gambar berpengaruh positif terhadap hasil belajar IPA siswa kelas V SD di Gugus V Kecamatan Banjar, Kabupaten Buleleng tahun ajaran 2017/2018. 
Saran yang dapat disampaikan berdasarkan penelitian yang telah dilakukan adalah sebagai berikut; 1) Bagi Kepala Sekolah, untuk menciptakan kualitas pendidikan yang lebih baik, hendaknya kepala sekolah mengikutsertakan guru untuk mengikuti berbagai seminar atau pelatihan-pelatihan mengenai pembelajaran yang kooperatif, 2) Bagi Guru, diharapkan kepada guru hendaknya memilih pembelajaran yang kooperatif, seperti pembelajaran menggunakan model pembelajaran tipe jigsaw untuk meningkatkan hasil belajar siswa. 3) Bagi Siswa, hendaknya mempertahankan rasa tanggung jawab dalam mengerjakan tugas kelompok dan mengikuti pembelajaran dengan aktif, dan 4) Bagi para peneliti lain yang berminat mengadakan penelitian lebih lanjut dan sejenis tentang pembelajaran kooperatif berbantuan media gambar hendaknya lebih memperhatikan kendala-kendala yang dihadapi siswa dalam pembelajaran serta mengupayakan solusi pemecahan yang tepat agar penelitian yang dilaksanakan dapat mencapai hasil yang lebih maksimal.

\section{Daftar Pustaka}

Djamarah, Bahri dan Aswan Zain. 2006. Strategi Belajar Mengajar.Jakarta : Rineka Cipta.

Karisma, Liana. 2015."Penerapan Model Pembelajaran jigsaw Pada Mata Pelajaran IPA Untuk Meningkatkan Hasil Belajar Siswa Kelas IV'. Singaraja: Jurnal PGSD Universitas Pendidikan Ganesha. Vol 3 No: 1.

Kurniasih, Imas dan Berlin Sani. 2015. Ragam Pengembangan Model Pembelajaran untuk meningkatkan professional guru.

Mudlofir,Ali dan Evi Fatimatur 2016. Desain Pembelajaran Inovatif. Jakarta: Raja : PT Rajagrafindo Persada. Jakarta: kata Pena.

Rusman. 2017. Belajar Dan Pembelajaran Berorientasi Standar Proses Pendidikan. Jakarta: Kencana.

Sahin, Abdullah. 2010. Effects of jigsaw II technique on academic achievement and attitudes to written expression course. Turkey: Department of Turkish Education, Erzurum, Faculty of Education, Atatürk University. Vol. 5(12),

Tegeh, I Made. 2010. Media Pemblajaran. Seri Buku Ajar Perguruan Tinggi.Singaraja: Undiksha 